\title{
ENTREVISTA - Wagner Rodrigues Valente
}

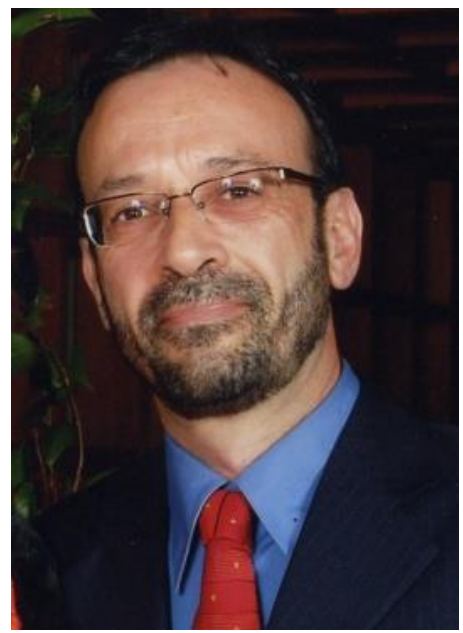

Prof. Dr. Wagner Rodrigues Valente possui graduação em Engenharia (Escola Politécnica) pela Universidade de São Paulo (1979) e Pedagogia pela Universidade Santa Cecília dos Bandeirantes (1987), mestrado em Educação: História e Filosofia da Educação pela Pontifícia Universidade Católica de São Paulo (1991) e doutorado em Educação pela Universidade de São Paulo/ INRP- Paris (1997). Pós-Doutorado pela Pontifícia Universidade Católica de São Paulo (1999). Livre Docente no Departamento de Educação da Universidade Federal de São Paulo (2010). É coordenador do GHEMAT - Grupo de Pesquisa de História da Educação Matemática (www.unifesp.br/centros/ghemat) e professor Adjunto da Universidade Federal de São Paulo. Tem experiência na área de Educação, com ênfase na Educação Matemática. Na pesquisa investiga principalmente os seguintes temas: livro didático de matemática, didática da matemática, história da educação matemática e história da matemática.

\section{1) Quando surgiu o seu interesse sobre as questões voltadas para a História da Educação Matemática?}

A partir de minha dissertação de mestrado interessei-me por discutir "o saber docente". Considerava, àquela altura - idos de 1986 - que algo mais haveria no saber envolvido na prática pedagógica do professor, que não poderia ser explicado por uma questão de transposição didática. Em suma: a escola poderia ser também um lugar produtor de conhecimento. Desde esse momento, tomei contato com os estudos do pesquisador André Chervel, sobre história das disciplinas escolares. Daí, busquei uma bolsa de doutorado-sanduíche em Paris, cidade onde Chervel integrava um grupo de pesquisa. Em Paris, estagiei no INRP - Institut National de RécherchePédagogique sob orientação do Prof. Dr. Bruno Belhoste, especialista em história da matemática e educação matemática. Por fim, elaborei a tese que se intitulou "Uma história da 
matemática escolar no Brasil, 1730-1930” já publicada em livro em com mais de uma edição, em 1999.

\section{2) Prof. Wagner, como você vê a pesquisa em História da Educação Matemática} no Brasil hoje?

Vejo-a como um campo em pleno desenvolvimento e rico em possibilidades de projetos e pesquisas. Os recentes encontros nacionais e internacionais demonstram isso, bem como os vários números temáticos de periódicos importantes brasileiros e estrangeiros. Atente-se para a realização, por exemplo, do III CIHEM - Congresso Ibero-americano de História da Educação Matemática, em novembro de 2015, em Belém do Pará.

3) Em sua opinião quais são os desafios e dificuldades em relação às pesquisas voltadas para esta linha de estudo?

Uma síntese as discussões atuais e dos desafios para essa linha de estudo está colocada na publicação da obra "História da Educação Matemática no Brasil" que tive a honra de organizar, editada em 2014. Na obra, um trabalho coletivo que envolveu várias dezenas de pesquisadores do país, estão presentes discussões sobre problemáticas de pesquisa, sobre fontes, sobre referências teórico-metodológicas e um apanhado da produção existente até o presente. No capítulo final, me parece, está colocado um dos maiores desafios para a história da educação matemática: tornar-se um campo científico. Passado um ano dessa produção, que teve como referência os debates e estudos presentes no I ENAPHEM - Encontro Nacional de Pesquisas em História da Educação Matemática, mais e mais vem ganhando espaço as discussões sobre o papel da história da educação matemática na formação de professores. Esse poderia ser um tema aglutinador para o III ENAPHEM, a ser realizado em 2016 na cidade de São Mateus, no estado do Espírito Santo. Lembro, ainda, que está para vir à luz uma nova publicação, que tem por origem o II Encontro realizado na UNESP de Bauru, em 2013, sob a coordenação do Prof. Dr. Vicente Garnica. Tal obra atualizará ainda mais as discussões sobre essa linha de pesquisa.

\section{4) A disciplina de História da Matemática é ministrada atualmente em vários cursos de licenciatura em Matemática em universidades brasileiras, porém a}


disciplina de História da Educação Matemática ainda é pouco inserida no currículo. Porque isso acontece? Qual seu posicionamento sobre esse fato? Qual a importância da disciplina de História da Educação Matemática para a formação desse futuro professor?

Vejam-se as minhas ponderações na pergunta que busquei responder anteriormente. De fato, tem-se consolidada a disciplina História da Matemática, no entanto, a produção sobre história da educação matemática vem demonstrando a autonomia relativa desta última. Os resultados das pesquisas mostram que a história da educação matemática não é um subconjunto da História da Matemática, considerada classicamente a partir dos manuais utilizados nos cursos de licenciatura em Matemática. E tanto mais consolidadas ficarão as pesquisas sobre história da educação matemática quanto mais elas se revelarem fundamentais na formação do futuro professor de matemática. Em textos anteriores busquei demonstrar que os professores de matemática não têm os matemáticos com herdeiros profissionais, pertencem a outra linhagem, aquela dedicada ao ensino...

5) Relate um pouco sobre como é trabalhar com pesquisa em História da Educação Matemática. Que sugestões/conselhos você daria para um iniciante que irá desenvolver estudos nessa área?

É sempre muito difícil esse tipo de pergunta, pois ela implica em processos, processos de formação. Talvez pudesse dizer que a minha experiência pessoal revela que a participação em grupos de pesquisas, em projetos coletivos, é um modo muito importante de formar-se pesquisador. Rompendo com certa tradição do trabalho solitário, a atividade de pesquisa conjunta, sob um tema que interesse a vários pesquisadores constitui ambiente formador muito rico. É assim que temos trabalhado com alunos da graduação nos seus estudos de iniciação científica, de monografias de conclusão de curso; com alunos de pós-graduação em seus mestrados e doutorados; e mesmo na orientação de pós-doutorados, no âmbito do GHEMAT - Grupo de Pesquisa de História da Educação Matemática http://www2.unifesp.br/centros/ghemat/. 